\title{
21. FLUID FLOW WITHIN THE BARBADOS RIDGE COMPLEX, PART I: DEWATERING WITHIN THE TOE OF THE PRISM 1
}

\author{
Elizabeth J. Screaton, ${ }^{2,3}$ Dennis R. Wuthrich, ${ }^{2,4}$ and Shirley J. Dreiss ${ }^{2}$
}

\begin{abstract}
Sediment compaction at convergent margins expels pore fluids, which in turn influence many aspects of subduction zone geology. Drilling in the Barbados Ridge complex during ODP Leg 110 and DSDP Leg 78A provided information about sediment types, porosities, and the geometry of the complex. In this paper, we use these observations to estimate the rates of sediment porosity loss and accompanying fluid expulsion from the prism, the décollement, and the underthrust sediments. Rates of porosity loss depend on how rapidly the sediments move arcward through the complex. We compute rates of sediment movement in the prism and décollement as a function of distance from the deformation front. This calculation assumes that the rates of sediment movement decrease arcward as the result of porosity loss in the prism and décollement and thickening of the prism. According to computed rates of sediment movement for the prism, sediment deceleration is greatest within the first 3 to $5 \mathrm{~km}$ arcward from the deformation front. Similarly, most dewatering of the prism sediments takes place in this region. Beyond $5 \mathrm{~km}$, rates of sediment dewatering become greatest in the underthrust sediments, assuming these sediments are carried downward at a uniform rate with the oceanic plate.
\end{abstract}

\section{INTRODUCTION}

At sediment-rich subduction zones, highly porous sediments are deformed by tectonic and gravitational stresses as they are either accreted or underthrust. Fluids expelled from the compacting sediments influence many aspects of subduction zone geology, including heat transport (Langseth and Hobart, 1984), diagenesis and metamorphism (Etheridge et al., 1983), and benthic biology (Kulm et al., 1986). In addition, the relative rates of sediment loading and fluid dissipation determine the magnitude and distribution of excess pore pressures. These excess pore pressures may affect the shape of the accretionary wedge (Davis et al., 1983) as well as thrust fault and fold geometries (Hubbert and Rubey, 1959; Seely, 1977).

Despite the importance of fluids at convergent margins, little is known about the rates and directions of fluid flow and the pore-pressure distributions in these settings. The Barbados Ridge complex is primarily composed of fine-grained sediments (Marlow et al., 1984) and represents a low-permeability end member of accretionary complexes. In the Barbados complex, an extensive décollement zone separates the downgoing Atlantic ocean crust from the accretionary prism of the over-riding Caribbean Plate. Above the décollement, sediments are off-scraped, building up the accretionary prism and causing the deformation front to grow seaward. As these accreted sediments are deformed by tectonic compression and loading, they compact and lose porosity. Beneath the décollement, the sediments move with the downgoing plate. Tectonic stresses and the weight of the over-riding prism cause vertical compaction and porosity loss within these underthrust sediments.

At Sites 671 and 672, ODP Leg 110 succeeded in drilling through the décollement zone. Sediment and pore-water sam-

\footnotetext{
${ }^{1}$ Moore, J. C., Mascle, A., 1990. Proc. ODP, Sci. Results, 110: College Station, TX (Ocean Drilling Program).

2 Earth Sciences Board, University of California at Santa Cruz, Santa Cruz, CA 95064 .

3 Current address: Harding Lawson and Associates, P.0. Box 578, 7655 Redwood Blvd., Novato, CA 94948.

${ }^{4}$ Current address: Geomatrix Consultants, One Market Plaza, Spear Street Tower, San Francisco, CA 94105
}

ples collected from these sites contained chemical, thermal, and structural evidence of preferential fluid migration along the décollement (Moore, Mascle, et al., 1987). In addition, the Leg 110 drilling, along with previous drilling and seismic reflection studies, provided information on the structure and physical properties of sediments within the accretionary prism, the décollement, and the underthrust series. In this study, we use these observations to construct a numerical model of fluid flow in the toe of Barbados Ridge complex.

Fluid migration through the toe of the complex results primarily from sediment compaction and porosity loss. Therefore, to describe the fluid flow, we must examine the fluxes of both solids and fluids. This paper is the first of a two-part series describing the hydrogeologic modeling. Here, we quantify the rate and distribution of sediment porosity loss. To do this, we extrapolate a porosity distribution for the accretionary prism and the décollement from borehole porosity data. We use this distribution, the geometry of the complex, and equations for the conservation of solid mass to estimate the rates of sediment movement as a function of distance from the deformation front. We then compute rates of porosity loss and associated fluid expulsion throughout the complex. The second paper (Wuthrich et al., this volume) describes the fluid flow model and simulated pore pressures and flow patterns, using the estimated rates of porosity loss to approximate the effects of sediment deformation.

\section{PHYSICAL SETTING}

The Barbados Ridge complex (Fig. 1A) varies in width from $450 \mathrm{~km}$ in the south to $260 \mathrm{~km}$ in the vicinity of the ODP Leg 110 and DSDP Leg 78A transects (Moore and Biju-Duval, 1984). A number of studies have suggested that the Caribbean and North American Plates converge at a relatively slow rate of 2.0 to $2.2 \mathrm{~cm} / \mathrm{yr}$ in an east-west direction (MacDonald and Holcombe, 1978; Minster and Jordan, 1978; Tovish and Schubert, 1978; Dorel, 1981). MacDonald and Holcombe (1978) estimate that this rate has been constant for the last $2.4 \mathrm{~m}$.y. Alternatively, Sykes et al. (1982) suggest a much higher convergence rate of $4.0 \mathrm{~cm} / \mathrm{yr}$ in an east-northeast direction for the last 7 m.y. Stein et al. (1988) review these estimates and conclude that $2.0 \mathrm{~cm} / \mathrm{yr}$ is most plausible. 


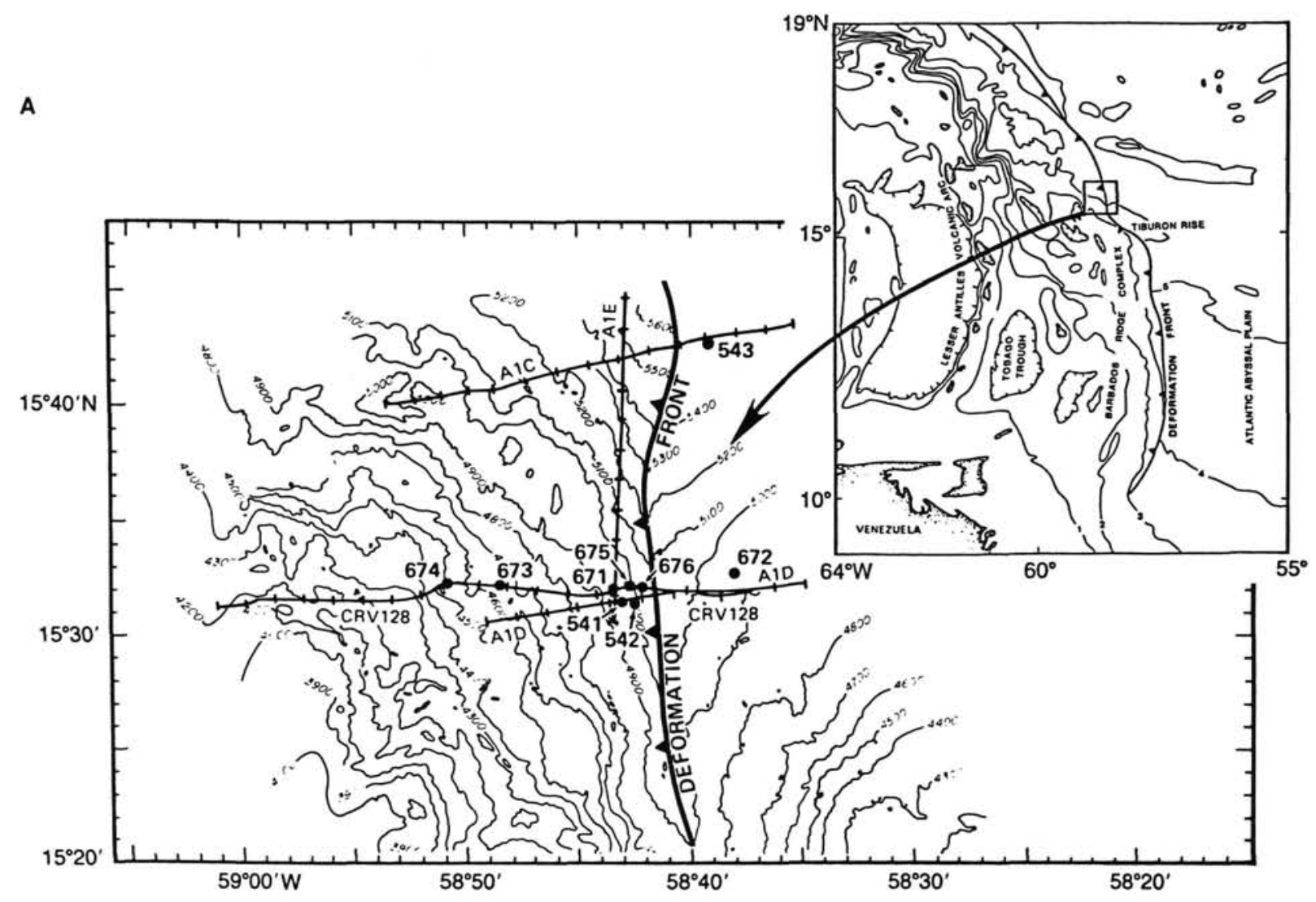

B

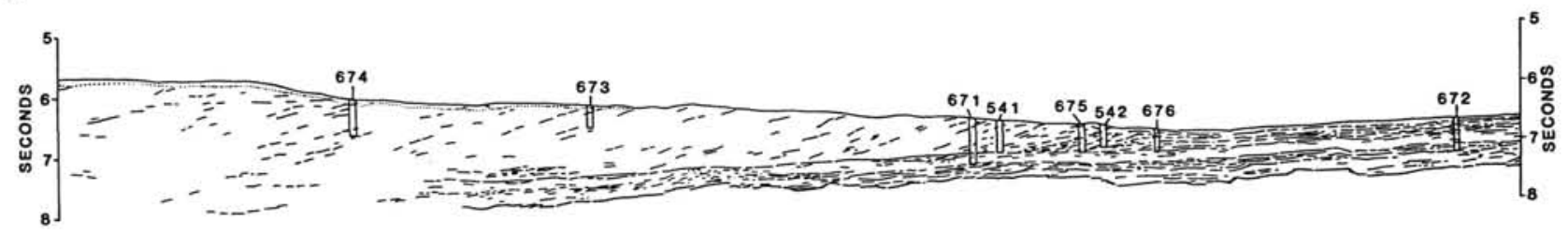

Figure 1. (A) Location map showing sites drilled during ODP Leg 110 and DSDP Leg 78A, and the network of seismic reflection lines (from Mascle, Moore, et al., 1988). (B) Interpretation of seismic line CRV128 and projected sites of ODP Leg 110 and DSDP Leg 78A drill holes (from Moore, Mascle, et al., 1988).

The complex decreases in thickness to the north because of the greater distance from the South American continent, the primary source of the terrigenous sediments that make up most of the southern portion of the complex (Moore and Biju-Duval, 1984). At the latitude of ODP Leg 110, approximately twothirds of the 700-m-thick section of incoming sediments are underthrust while one-third is off-scraped (Biju-Duval and Moore et al., 1984). The incoming sequence is composed mainly of very fine-grained pelagic and hemipelagic sediments (Wright, 1984).

The prism consists of calcareous muds and mudstones (Mascle, Moore, et al., 1988) that have been imbricately thrust during the accretion and subsequent thickening of the accretionary prism. The décollement zone, seen as a prominent reflector in seismic reflection profiles, separates the discontinuously reflective sediments of the accretionary prism from the acoustically layered underthrust sediments. These underthrust sediments are primarily interlayered mudstones, marlstones, siltstones, and sandstones.
The décollement is a laterally extensive zone of deformation characterized by a scaly fabric. At Site 671 , sediments recovered within this approximately 40-m-thick zone consist of lower Miocene radiolarian-bearing mudstones. This interval correlates with equivalent sediments at the ODP reference Site 672, located 6 $\mathrm{km}$ seaward of the deformation front. Low-angle shear zones and normal and reverse faults at Site 672 suggest incipient seaward propagation of the décollement at this stratigraphic level. Arcward of the deformation front, seismic reflection profiles indicate that the décollement follows the same stratigraphic horizon for $12 \mathrm{~km}$, then follows a deeper stratigraphic horizon arcward of Site 673 (Mascle, Moore, et al., 1988).

The age of sediments incorporated into the prism roughly constrains the time since accretion of sediments at various distances from the deformation front. Brown et al. (this volume) suggest that sediments presently at Site 671 entered the deformation front in the mid-upper Pleistocene. Sediments at Site $674,18 \mathrm{~km}$ arcward of the deformation front, accreted more recently than the late Pliocene, approximately $2 \mathrm{Ma}$ (Brown et al., 
this volume). Alternatively, Mascle, Moore et al. (1988) suggest that the sediments at Site $\mathbf{6 7 4}$ may have accreted as much as 5 Ma.

\section{CONCEPTUAL BACKGROUND}

This study examines a cross-section along seismic line CRV128 (Fig. IB). Borehole information from DSDP Leg 78A and ODP Leg 110 is projected onto this line, Figure 2. The model covers an area that extends from $10 \mathrm{~km}$ seaward of the deformation front to $14 \mathrm{~km}$ arcward of the front. However, the analysis focuses mainly on the region between Site $672,6 \mathrm{~km}$ seaward of the deformation front, and Site 673, $12 \mathrm{~km}$ arcward of the front. Beyond Site 673, a general geometry can be estimated from the seismic profile, but little other information is available to constrain porosity estimates and boundary conditions.

We consider a vertical cross-section that is fixed at the deformation front, and therefore migrates seaward with time. This methodology follows the approach developed by Karig (1986) for the Nankai Trough prism. Because sediments deform differently within the prism, décollement, and underthrust series, we subdivide the region into these three domains. We assume that the rate, thickness, and physical properties of sediments entering each domain at the seaward boundary remain constant over time. Sediments remain within each domain and exit only at the arcward boundary. In addition, the geometries and porosity distributions of the prism, the décollement, and the underthrust sediments are assumed constant for the frame of reference fixed to the deformation front. Furthermore, we assume that the sediment rate of movement profile can be approximated as vertically uniform within each domain, although it differs between the three regions. The following sections discuss the bases for these assumptions.

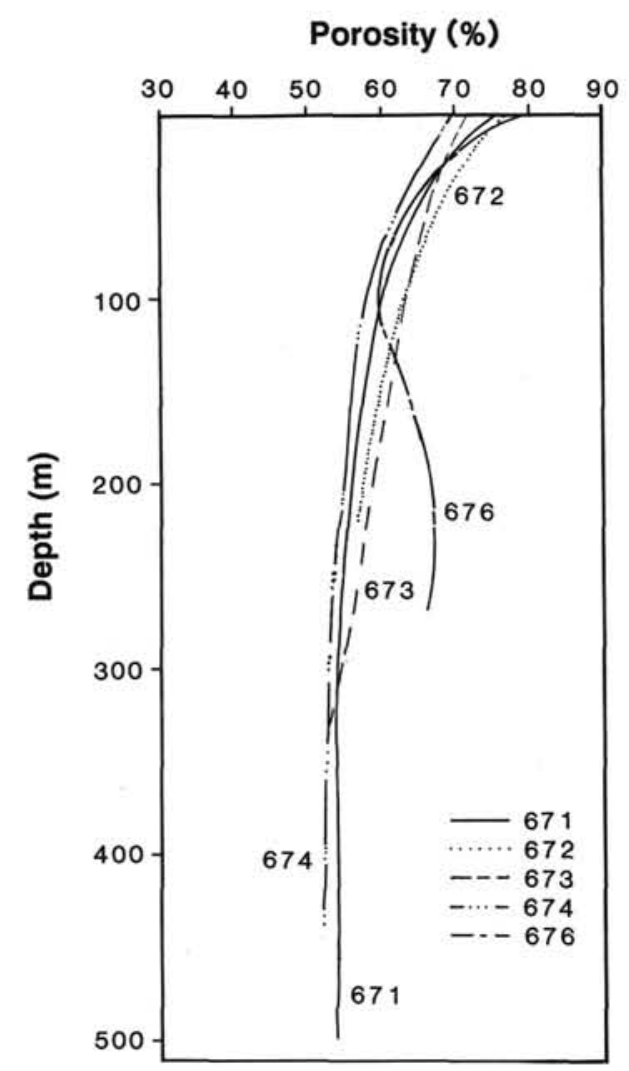

Figure 2. Smoothed porosity-depth curves derived from Leg 110 data.

\section{Model Assumptions}

The constant rate, thickness, and physical properties of sediments entering each domain at the seaward boundary require a constant rate of plate convergence. Considering the time since prism accretion and the 2.4-m.y. duration of constant convergence suggested by MacDonald and Holcombe (1978), this assumption is reasonable for prism sediments between the deformation front and a location between Site 671 and Site 673. This assumption also applies to all underthrust sediments in the model because these sediments would have entered the deformation front within the last $0.7 \mathrm{~m}$.y. (assuming a convergence rate of $2.0 \mathrm{~cm} / \mathrm{yr}$ from Stein et al. (1988)).

The lateral continuity of sediments within $5 \mathrm{~km}$ arcward of the deformation front suggests that lithologies and, consequently, physical properties of entering sediments have not changed greatly during the prism development in this area. Furthermore, the constant stratigraphic position of the décollement suggests that the relative percentages of accreted or subducted sediment thicknesses have remained approximately the same. Beyond Site 673, these assumptions do not hold; stratigraphic evidence shows that in the past, the décollement has followed a lower stratigraphic horizon, indicating either a previously thicker incoming section or underplating (Brown, Behrman, et al., this volume).

The assumption that sediments remain within each of the three domains and exit only at the arcward boundary is supported by the absence of evidence for underplating in the crosssection seaward of Site 673. At the top of the prism we assume that slope sedimentation is roughly balanced by erosion from other areas of the prism surface so that there is no net addition or subtraction of sediment across this boundary. We further assume that the geometries of the prism, the décollement, and the underthrust sediments are constant over time for a frame of reference fixed to the deformation front. Davis (1983) argues that the toe of an accretionary prism will maintain a critical taper in response to the forces acting upon the system. As new material is accreted, the prism grows seaward, deforming to maintain this critical taper. Therefore, in a frame of reference fixed to the deformation front, prism geometry does not vary with time.

Within a prism of constant geometry, the loading history of the sediments depends only on location relative to the deformation front if the effects of discrete failure such as thrust faults are neglected. Consequently, the degree of sediment consolidation depends only on location, sediment properties, and the rate of sediment influx. Thus, for a constant geometry, sediment type, and sediment influx, the porosity distribution does not vary with time. By similar reasoning, we consider that the geometry and porosity distribution of the underthrust sediments remain constant with time.

Finally, we approximate the horizontal components of the sediment motion profile as vertically uniform within each domain (i.e., $d \overrightarrow{\boldsymbol{V}}_{x} / d z=0$, where $\overrightarrow{\boldsymbol{V}}_{x}$ is the horizontal component of the sediment velocity). It is difficult to quantify the actual profiles in the prism and décollement because of the lack of information. Thus, as a first approximation, we use uniform horizontal components along a vertical profile. This assumption is similar to that made by Karig (1986) and Bray and Karig (1985).

\section{Modeling Approach}

Because the geometry and porosity distribution are constant with time, we can describe the flux of solids through the complex with equations of steady-state conservation of mass. Furthermore, once the spatial distribution of the rates of porosity loss, $\vec{\nabla} \cdot\left(n \vec{V}_{s}\right)$, is known, fluid pressures and velocities can be modeled as a steady-state fluid flow problem (Wuthrich et al., this volume). 
To quantify the rates of porosity loss, we apply the conservation of solid mass to sediment movement within the complex. With a uniform sediment influx at the seaward boundary, no sediment transfer between domains, and vertically uniform profiles of sediment movement rates, the total flux of solids across a vertical plane through a domain will not change with distance from the deformation front. In the prism, sediments slow down as the sediment column thickens and porosities decrease. Sediments in the décollement decelerate as the result of porosity loss only, because the thickness of this zone is assumed relatively uniform. Because assumed rates of movement for the underthrust sediments remain constant, a decrease in thickness must be accompanied by a proportional reduction in porosity in the underthrust sediments.

The computations are broken into three steps. First, we develop a porosity distribution for each of the three domains from the geometry of the complex, and the borehole porosity data. We then calculate the rates of sediment movement as a function of distance from the deformation front for the prism and décollement, using equations for conservation of mass of solids. Finally, we compute the spatial distribution of the rate of porosity loss, $\vec{\nabla} \cdot\left(n \vec{V}_{s}\right)$, in each domain.

\section{POROSITY DISTRIBUTION}

Available porosity data cover only scattered locations in the complex. To describe the porosity distribution from available borehole data, we developed two porosity-depth relationships, one for the prism and one for the décollement. Because data are scarce in the underthrust sediments, we estimated the porosity distribution in this region with a mass-balance approximation.

\section{Prism and Décollement}

We first plotted the porosity of prism samples (Mascle, Moore, et al., 1988) as a function of depth for each site from Leg 110. These porosity values were not corrected for rebound. As shown in Figure 2, porosity generally decreases with depth, although there are variations in profiles due to lithologic and structural complexities. Change in porosity with depth appears to be greatest within the first 50 to $100 \mathrm{~m}$ beneath the sedimentwater interface. Décollement sediments show a slightly greater porosity loss with depth than those of the prism (Fig. 3).

Figure 2 shows no clearly discernible trend in the porositydepth relationship with distance from the deformation front. Although such a trend may exist, it is obscured by lithologic variations. Moore, Mascle, et al. (1988) note a $3 \%$ porosity decrease between Sites 672 and 671 in sediments of the same lithology that have remained at similar depths. Sediments buried an additional $200 \mathrm{~m}$ down show a $13 \%$ porosity decrease between the two sites. Thus our use of a single porosity-depth relationship throughout the prism may underestimate porosity at the deformation front and overestimate it at the arcward boundary. As a result, the rate of porosity loss may be slightly underestimated.

To develop general descriptions of the porosity-depth relationship for the prism and the décollement, we fit two exponential equations by least squares to the porosity depth data (Fig. 4). The porosity-depth relationships for the prism and décollement sediments are curves of the form

$$
n=N \cdot \exp (-b \cdot z)
$$

where

$$
\begin{aligned}
& n=\text { porosity; } \\
& N=\text { a representative porosity at } z=0 ; \\
& b=\text { a constant determined in the curve fitting; and } \\
& z=\text { the depth from sediment-water interface. }
\end{aligned}
$$

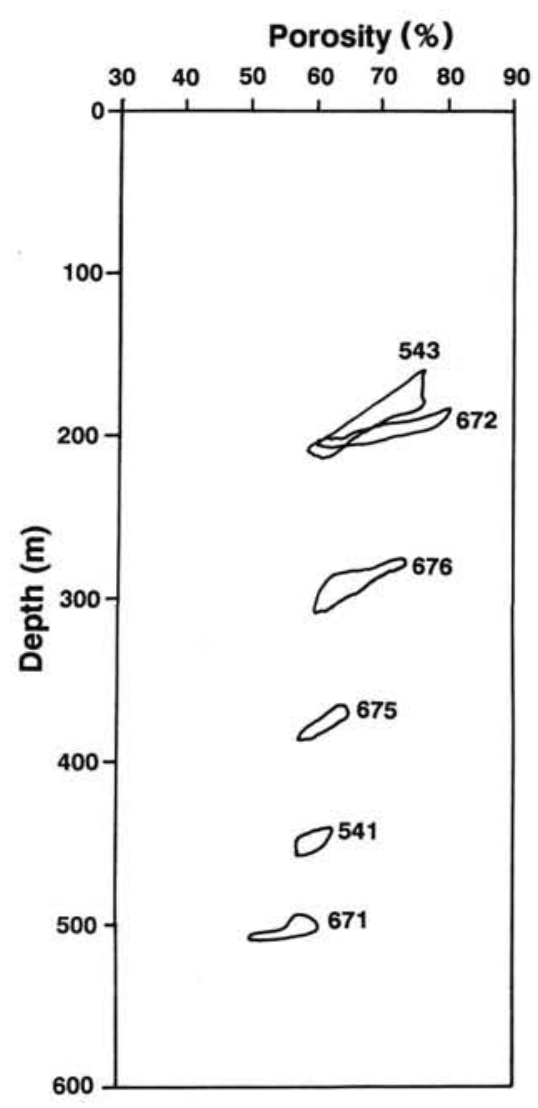

Figure 3. Porosity data for lower Miocene sediments (Moore, Mascle, et al., 1988). Numbers refer to DSDP and ODP sites.

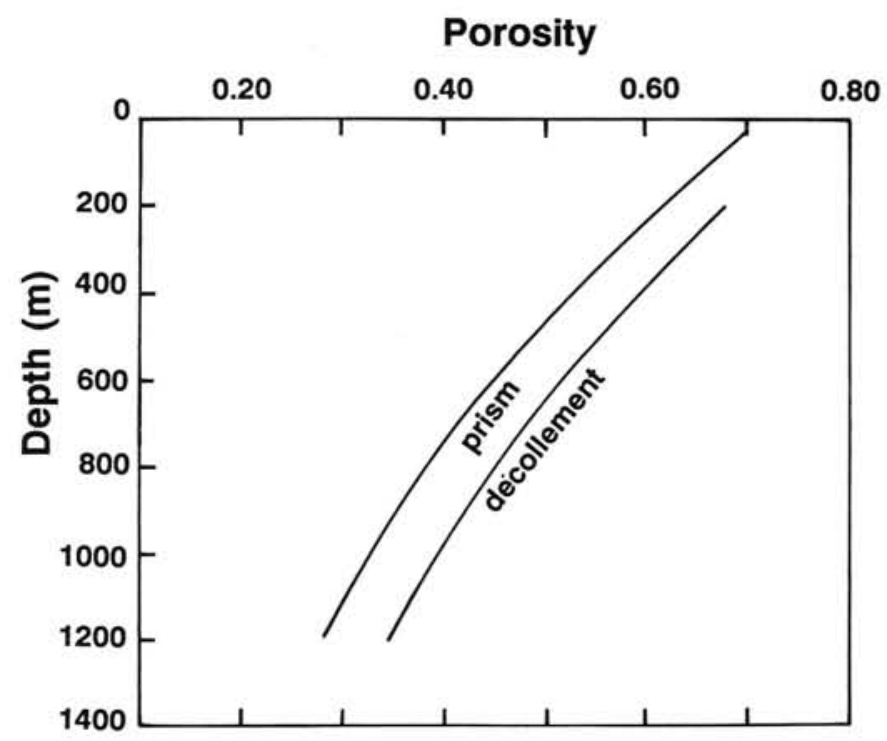

Figure 4. Porosity-depth curves for sediments in the prism and décollement. Curves are defined by Equation (1) where $b$ was determined from a least-squares fit to the data in Figures 2 and 3.

In the prism, $N$ is the average porosity of surface sediments. In the décollement, $N$ was found by extrapolation to $z=0$. For the prism, $N=0.715$ and $b=7.86 \times 10^{-4}$; for the décollement, $N$ $=0.78$, and $b=6.94-10^{-4}$. 


\section{Underthrust Sediments}

Only two boreholes, at Sites 671 and 672 , provide information on the underthrust sediments. Neither of these boreholes penetrated the full thickness of the underthrust series. Because of the scarcity of porosity measurements for the underthrust sediments, we estimated a porosity distribution from the change in thickness of these sediments. We assume that solid mass flux is the same across any vertical profile in the underthrust sediments. Thus, we can equate solid flux at two distances from the deformation front as

$$
\left(1-\bar{n}_{i}\right) \cdot \Delta z_{i} \cdot \vec{V}_{i}=\left(1-\bar{n}_{i+1}\right) \cdot \Delta z_{i+1} \cdot \vec{V}_{i+1}
$$

where

$\bar{n}_{i}=$ average porosity at $i$;

$\left(1-\bar{n}_{i}\right)=$ the average volume of solids in a unit sediment volume at $i$

$\Delta z_{i}=$ sediment column height at $i$; and

$\vec{V}_{i}=$ sediment rate of movement at $i$.

Because the underthrust sediments move at a constant rate, $\vec{V}_{i}=$ $\overrightarrow{\boldsymbol{V}}_{i+1}$ and

$$
\left(1-\bar{n}_{i}\right) \cdot \Delta z_{i}=\left(1-\bar{n}_{i+1}\right) \cdot \Delta z_{i+1} .
$$

Consequently, a loss in thickness of the sediment column is accompanied by a proportional porosity loss and we can solve for $\bar{n}_{i+1}$ using an average incoming porosity $\bar{n}_{i}$. The assigned porosities are uniform for any vertical profile and represent an average for the entire underthrust sequence. We approximated the decrease in sediment thickness using linear approximations of the irregular boundaries at the top and bottom of the underthrust series. Therefore, the average porosity in a vertical profile is a linear function of distance from the deformation front (Fig. 5). We assigned an initial incoming porosity of 0.60 at Site 672 based on porosity measurements and the assumption that underlying mudstones were slightly more porous than the collected sandy samples.

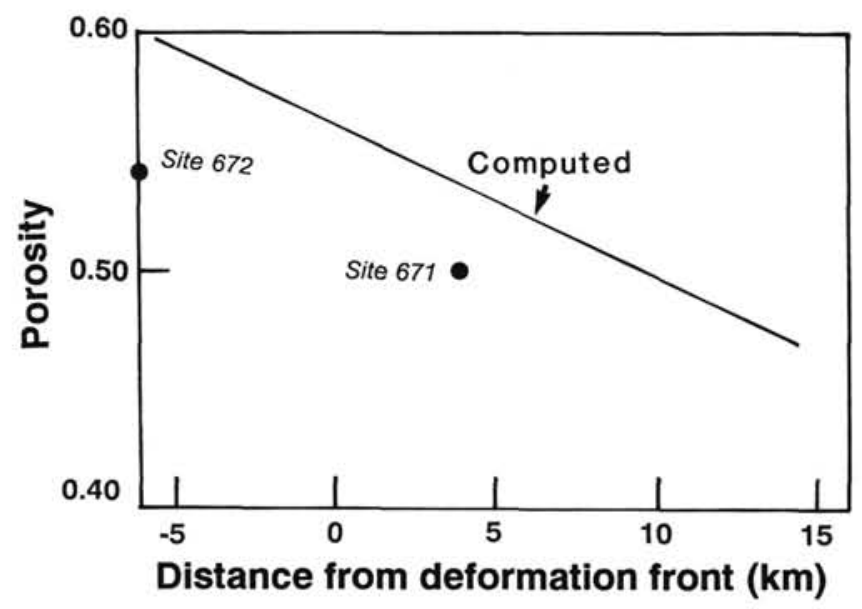

Figure 5. Change in porosities of underthrust sediments with distance arcward from Site 672. Dots represent averaged measured porosity values for sediments immediately below the décollement; the solid line is the porosity computed from the change in thickness of the underthrust sequence.

\section{Discussion}

Estimated porosities of the prism and décollement sediments entering the complex are higher than those of underthrust sediments (Fig. 6). Estimated porosities in the prism and décollement decrease rapidly with depth, while average porosities in the underthrust sediments are modeled to exhibit a more gradual linear decrease with distance from the deformation front.

Bray and Karig (1985) used seismic velocities to derive a porosity distribution for the Nankai Trough, which is sand-rich and consequently likely to be of higher permeability than the Barbados Ridge complex. The sediments of the Nankai Trough show greater porosity loss with depth than the sediments of the Barbados Ridge complex. At $0.5 \mathrm{~km}$ depth in the Nankai prism, Bray and Karig (1985) calculated porosities of approximately $0.30,46 \%$ of the surficial porosity. In contrast, the porositydepth curve for Barbados prism sediments indicates a porosity of 0.45 for the same depth, $63 \%$ of the surficial porosity. In addition, our treatment of the porosity data does not consider the arcward increase in the porosity-depth gradient observed by Bray and Karig (1985) in the Nankai Trough.

\section{ESTIMATION OF SEDIMENT RATES OF MOVEMENT}

Calculating rates of sediment movement as a function of distance from the deformation front follows from the conservation of mass of solids across a vertical plane of height $h_{i}$ and unit width located at position $i$. We assume that the density of the solids remains constant throughout the study area because depths are not great enough for metamorphic reactions. We also assume that the horizontal component of rate of movement, $\vec{V}_{x}$, is uniform with depth in each domain. Consequently, the mass flux of moving solids across any vertical plane is constant, and we can equate solid flux at any two distances from the deformation front as

$$
h_{i} \cdot\left(1-\bar{n}_{i}\right) \cdot \vec{V}_{x_{i}}=h_{i+1} \cdot\left(1-\bar{n}_{i+1}\right) \cdot \vec{V}_{x_{i+1}}
$$

where

$$
\begin{aligned}
h_{i}= & \text { height of the vertical plane at } i \\
\bar{n}_{i}= & \text { the mean porosity of the vertical plane at } i \text {, and } \\
\vec{V}_{x_{i}}= & \text { the horizontal rate of movement of the solids at posi- } \\
& \text { tion } i .
\end{aligned}
$$

Thus, the horizontal rate of movement is

$$
\overrightarrow{\boldsymbol{V}}_{x_{i+1}}=h_{i} \cdot \overrightarrow{\boldsymbol{V}}_{x_{i}} \cdot\left(1-\bar{n}_{i}\right) /\left(h_{i+1} \cdot\left(1-\bar{n}_{i+1}\right)\right)
$$

where $\bar{n}_{i}$ and $\bar{n}_{i+1}$ are found by integrating the porosity depth relationship in Equation (1) over the thickness of the prism or décollement and dividing by $h_{i}$ or $h_{i+1}$. For example, for the prism,

$$
\begin{gathered}
\bar{n}_{i}=\left[(-A / b) \exp \left(-b \cdot h_{i}\right)+A / b\right] / h_{i} \\
\text { Discussion }
\end{gathered}
$$

Figure 7 shows computed rates of sediment movement normalized by the initial rate of movement $\left(\vec{V}_{0}\right)$ of the incoming sediments as a function of distance from the deformation front. Rates of movement at the deformation front are slightly less than $\overrightarrow{V_{0}}$ because some porosity loss occurs between the seaward boundary and the deformation front. In the prism, the greatest decrease in rates of sediment movement occurs within the first 4-5 km from the deformation front. $\vec{V}_{x} / \vec{V}_{0}$ decreases to approxi- 
m

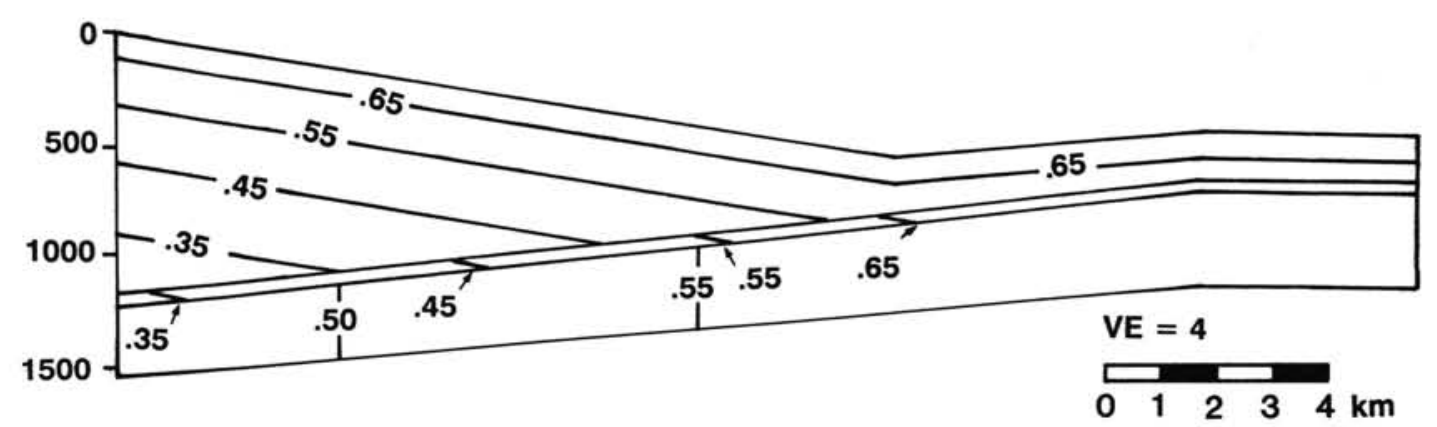

Figure 6. Estimated porosity distribution in the accretionary prism, the décollement, and the underthrust sediments.

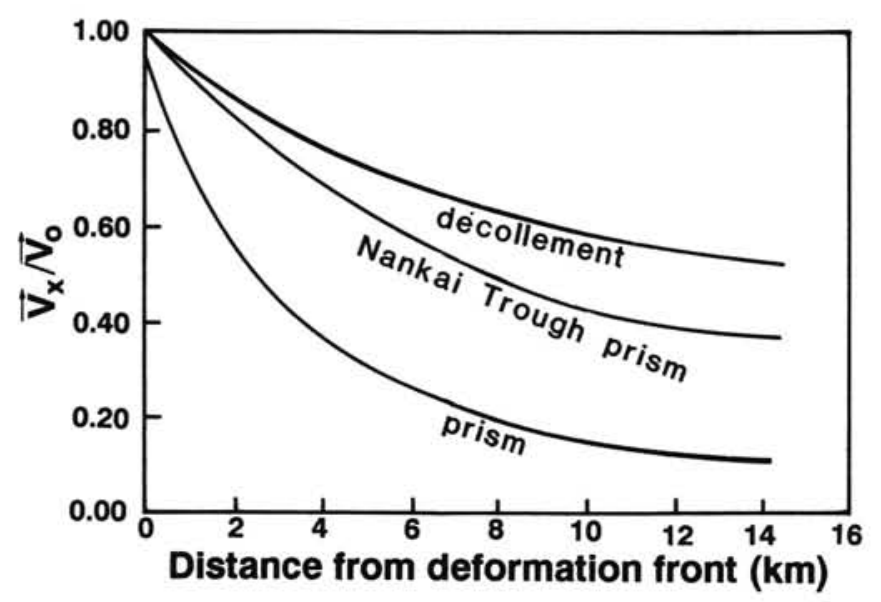

Figure 7. Normalized rates of sediment movement $\left(\vec{V}_{x} / \vec{V}_{0}\right)$ as a function of distance from the deformation front. Note that décollement sediments do not decelerate as rapidly as prism sediments. $\vec{V}_{x}$ decreases to $0.5 \overrightarrow{V_{0}}$ ) within $2.5 \mathrm{~km}$ of the deformation front, and approaches $0.1 \vec{V}_{0}$ at about $14 \mathrm{~km}$. $\vec{V}_{x} / \vec{V}_{0}$ for the Nankai Trough (Karig, 1986) are shown for comparison.

mately $0.30-0.40$ by this distance. In the next $10 \mathrm{~km}, \vec{V}_{x} / \vec{V}_{0}$ decreases less rapidly with distance to approximately 0.10 at $14 \mathrm{~km}$ from the deformation front. Because the toe of the accretionary prism moves seaward at the rate that sediment piles up against a backstop, this $10 \%$ of $\vec{V}_{0}$ may represent a rough upper bound for the rate of prism outgrowth. Sediments in the décollement decelerate less quickly than those in the prism, because we have assumed that the thickness of this zone does not change.

Comparing the computed time since accretion with ages inferred from lithologies provides a check on our calculations. The time required for sediments to move through the prism can be estimated by integrating equation 5 over the distance from the deformation front. For this integration, height and porosity must be stated as a function of distance from the deformation front. In addition, we assume an incoming rate of movement, $\overrightarrow{V_{0}}$, of $2.0 \mathrm{~cm} / \mathrm{yr}$. This rate is at the lower end of the range of estimates and assumes that the rate of deformation front advancement is small relative to the convergence rate.

The results of these calculations suggest that sediments move to Site $671,4 \mathrm{~km}$ from the deformation front in approximately 0.4 m.y. (Fig. 8). This falls within the middle-upper Pleistocene limit inferred from lithologic constraints. At $12 \mathrm{~km}$ from the deformation front, the computations indicate an age of accretion of approximately $2.3 \mathrm{~m}$.y. This age is consistent with estimates

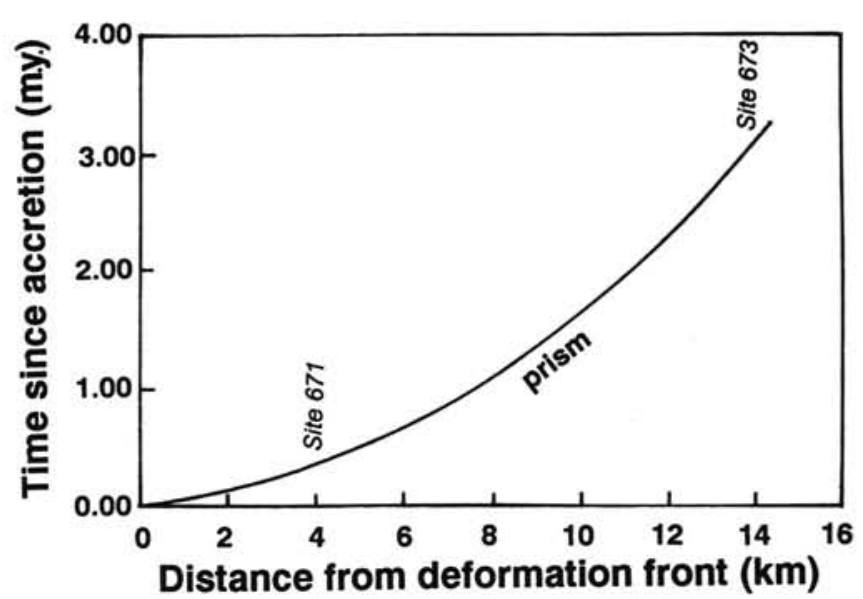

Figure 8. Time since accretion of prism sediments as a function of distance from the deformation front.

by Mascle, Moore, et al. (1988) and Brown et al. (this volume) of between 2 and $5 \mathrm{Ma}$ at Site 674, $6 \mathrm{~km}$ further arcward.

Karig (1986) performed similar computations of rates of sediment movement with distance from the deformation front for the accretionary prism at the Nankai Trough, using the instantaneous decrease in rates of sediment movement (the slope of the curve in Fig. 7) as a measure of horizontal shortening at a point in the prism. The Nankai Trough has a convergence rate similar to this area of the Barbados Ridge complex, a similar angle between the trench slope and the oceanic crust, but a greater thickness of incoming sediments (Karig, 1986). As in Barbados, the instantaneous rate of shortening in the Nankai Prism is greatest within approximately the first $5 \mathrm{~km}$ from the deformation front. However, despite the greater porosity loss with depth in the Nankai Trough, normalized rates of sediment movement are greater for any distance from the deformation front than for similar distances in the modeled area of the Barbados Ridge complex. Because the incoming thickness of sediments in Nankai is greater than that of Barbados while prism geometry is similar, less thickening and accompanying loss in rates of sediment movement is needed to form the Nankai prism.

\section{ESTIMATION OF RATES OF POROSITY LOSS}

Quantifying rates of sediment movement allows us to estimate porosity loss and fluid expulsion rates throughout the complex. These rates are used in the fluid flow model to account for the movement and deformation of the sediments. 
Wuthrich et al. (this volume) explain the mathematical basis for this procedure. $\vec{\nabla} \cdot\left(n \vec{V}_{s}\right)$ represents the rate of porosity loss in a fixed control volume, and is related to the divergence of the bulk sediment volume flux, $\overrightarrow{\boldsymbol{V}} \cdot \overrightarrow{\boldsymbol{Q}}_{b}$, by

$$
\vec{\nabla} \cdot\left(\vec{Q}_{b}\right)=\vec{\nabla} \cdot\left(n \vec{V}_{s} A\right)+\vec{\nabla} \cdot\left[(1-n) \vec{V}_{s} A\right]
$$

where $\vec{V}_{s}$ is the rate of motion of solids and $A$ is the area normal to $\vec{V}_{s}$.

In the fluid flow model, we assign a finite-element grid over the cross-section of the accretionary complex (Fig. 2 in Wuthrich et al., this volume). We discretely approximate the rates of porosity loss in a cell around each nodal point in the grid (Fig. 9). To simplify computations, we define the geometry of a cell around each node such that the influx of moving solids across the seaward boundary equals the outflux of solids across the arcward boundary, approximated as $\left(\vec{V}_{s} \Delta z(1-\bar{n})\right)_{i-1 / 2}=$ $\left(\vec{V}_{s} \Delta z(1-\bar{n})\right)_{i+1 / 2}$. Using this definition of the cell geometry permits the following approximations:

$$
\begin{gathered}
\vec{\nabla} \cdot\left(n \vec{V}_{s}\right) \approx \frac{d\left(n \vec{V}_{s}\right)}{d x} \\
\vec{\nabla} \cdot\left((1-n) \vec{V}_{s}\right) \approx \frac{d\left((1-n) \vec{V}_{s}\right)}{d x}
\end{gathered}
$$

and

$$
\vec{\nabla} \cdot\left(\vec{q}_{b}\right) \approx \frac{d\left(\vec{V}_{s}\right)}{d x}
$$

where $\vec{q}_{b}$ is the specific discharge of the bulk sediment volume and $\vec{Q}_{\mathrm{b}}=\vec{q}_{b} \cdot A$. For example, in Figure 9, the total solid flux is the same across vertical planes at $i-1 / 2$ and $i+1 / 2$. Because the porosity and the rate of movement of solids decrease arcward, the height of the cell increases. We iteratively search for $\Delta z_{i-1 / 2}$ and $\Delta z_{i+1 / 2}$ such that the flux of solids across each of the cell boundaries is equal to the flux across $\Delta z_{i}$. From (7) and (8),

$$
\frac{d\left(\bar{n} \overrightarrow{\boldsymbol{V}}_{s}\right)}{d x}=\frac{d \overrightarrow{\boldsymbol{q}}_{b}}{d x}-\frac{d\left((1-\bar{n}) \overrightarrow{\boldsymbol{V}}_{s}\right)}{d x}
$$

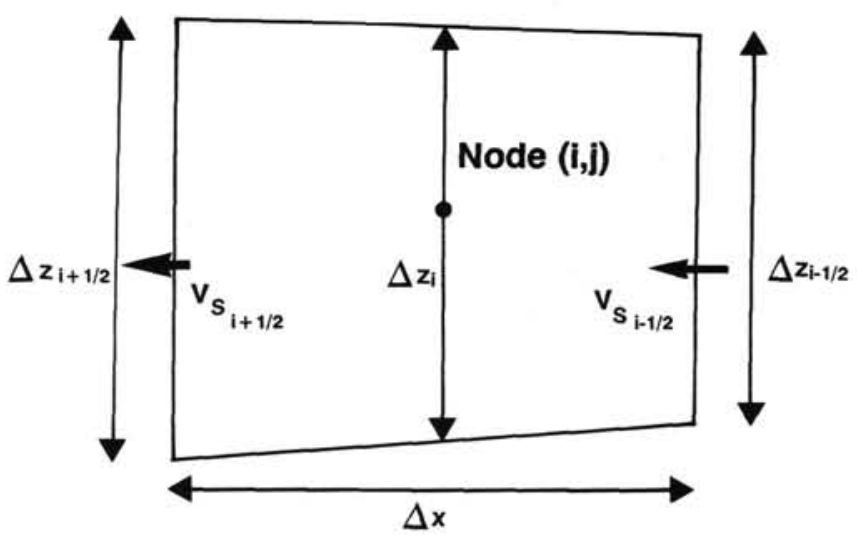

Figure 9. Diagram of a representative discrete cell. Positions $i+1 / 2$ and $i-1 / 2$ are located at the midway points to the nearest arcward and seaward nodes, respectively. The height of the cell at $i+1 / 2$ and $i-$ $1 / 2$ was specified such that the solid influx through the seaward boundary equals the outflux across the arcward boundary. where $n$ is the mean porosity over $\Delta z$. Because we specify the cell geometry so that the solid flux does not change through the cell,

$$
\frac{d\left((1-\bar{n}) \vec{V}_{s}\right)}{d x}=0
$$

and

$$
\frac{d \overrightarrow{\boldsymbol{q}}_{b}}{d x}=\frac{d\left(\bar{n} \vec{V}_{s}\right)}{d x}=\frac{d\left(\vec{V}_{s}\right)}{d x}
$$

Thus the volumetric rate of porosity loss or fluid expulsion associated with each of the nodal points in the finite-element grid may be approximated as

$$
\begin{aligned}
\frac{d \vec{Q}_{b}}{d x}= & \left(\vec{V}_{s_{i}-1 / 2} \Delta z_{i-1 / 2} \Delta y\right) \\
& -\left(\vec{V}_{s_{i}+1 / 2} \Delta z_{i+1 / 2} \Delta y\right)
\end{aligned}
$$

where $\Delta y$ is a unit distance perpendicular to the cross section.

\section{RESULTS}

Figure 10 illustrates the distribution of fluid production and porosity loss in terms of the volume of fluid produced per unit volume of the modeled region. The highest rates of fluid expulsion occur in the prism and décollement within the first $5 \mathrm{~km}$ arcward of the deformation front. The computed rate of porosity loss in the underthrust sediments is approximately uniform because we have assigned linear boundaries to the top and bottom of this domain and because sediment rate of movement in this domain is assumed to be constant. Beyond $5 \mathrm{~km}$ from the deformation front, the highest rate of fluid expulsion occurs in the underthrust sediments.

The total rates of fluid expulsion within the prism, décollement, and underthrust sediments are shown in Table 1. This table also presents estimates of the total amount of saturated pore space entering at the seaward boundary of each domain. These results assume a convergence rate of $2.0 \mathrm{~cm} / \mathrm{yr}$; a higher convergence rate would result in a proportional increase in the estimated fluid expulsion rate. The amount of water carried with the sediments into each domain is a function of the incoming sediment porosity and thickness. For example, the flux of water entering with the underthrust sediments is approximately 1.8 times the flux entering with accreted sediments. This difference in fluid influx reflects the fact that the incoming thickness of underthrust sediments is twice that of the accreting sediments Although the underthrust sediments have a lower average porosity.

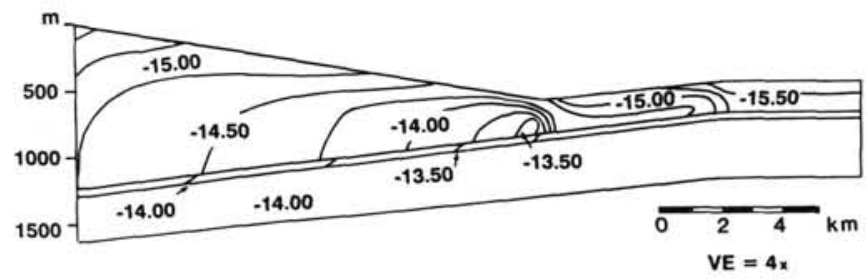

Figure 10. Values are the $\log$ of the rate of fluid expulsion $\left(\mathrm{m}^{3} / \mathrm{s}\right)$ percent volume of the modeled region $\left(\mathrm{m}^{3}\right)$ for a convergence rate of 2.0 $\mathrm{cm} / \mathrm{yr}$. Note that fluid expulsion rates increase with depth within the prism and decrease arcward from the deformation front. Expulsion rates in the prism exceed those of the underthrust sediments only within $5 \mathrm{~km}$ of the deformation front. 
Table 1. Summary of fluid expulsion rates.

\begin{tabular}{lccc}
\hline & Prism & Décollement & Underthrust \\
\hline Total fluid generation $\left(10^{-8} \mathrm{~m}^{3} / \mathrm{s}\right)$ & 4.87 & 1.53 & 6.57 \\
$\left(\mathrm{~m}^{3} / \mathrm{yr}\right)$ & 1.53 & 0.48 & 2.07 \\
$\begin{array}{l}\text { Saturated pore volume crossing } \\
\quad \text { seaward boundary }\left(10^{-8} \mathrm{~m}^{3} / \mathrm{s}\right)\end{array}$ & 8.78 & 2.09 & 15.8 \\
$\mathrm{~m}^{3 / \mathrm{yr}}$ & 2.77 & 0.66 & 4.99 \\
$\begin{array}{l}\text { Maximum flux across arcward } \\
\quad \text { boundary }\left(10^{-8} \mathrm{~m}^{3} / \mathrm{s}\right)\end{array}$ & 0.0 & 0.44 & 8.15 \\
$\mathrm{~m}^{3 / \mathrm{yr}}$ & 0.0 & 0.14 & 2.57 \\
\hline
\end{tabular}

Figure 11 shows cumulative fluid expulsion rates in each domain as a function of distance from the deformation front. Within the $10 \mathrm{~km}$ arcward of the deformation front, the underthrust sediments expel approximately $1.6 \mathrm{~m}^{3} / \mathrm{yr}$, or $34 \%$ of the original pore-volume flux entering this domain. In the same distance, the décollement sediments expel $0.43 \mathrm{~m}^{3} / \mathrm{yr}$, or $65 \%$ of the original pore-volume flux, and the prism sediments expel $1.25 \mathrm{~m}^{3} / \mathrm{yr}, 45 \%$ of the original pore-volume flux.

\section{Estimation of Flux at Arcward Boundary}

The presence of thermogenic methane at Sites 672 and 671 indicates that fluids flow through the décollement and underthrust sediments from deeper regions of the complex beyond the arcward boundary of the modeled region (Vrolijk, this volume). We can use the computations of fluid expulsion rates to estimate a maximum rate of fluid flow that might enter the modeled region at the arcward boundary. We assume that sediments dewater to a minimum porosity of 0.10 beyond the arcward boundary and that the present geometry can be extrapolated beyond this boundary. In addition, we assume that all water produced in the décollement and underthrust sediments moves laterally along the décollement and underthrust sediments into the model region and that no water crosses the arcward boundary in the prism. The sum of the maximum fluid flows across the arcward boundary for the underthrust and décollement sediments is $\mathbf{2 . 7}$ $\mathrm{m}^{3} / \mathrm{yr}$ (Table 1 ). This is approximately equal to the total computed rate of water production within the modeled region.

\section{SUMMARY AND CONCLUSIONS}

1. Estimates of rates of sediment movement across the accretionary prism indicate that the deceleration of sediments is greatest within the first $5 \mathrm{~km}$ from the deformation front. Similarly, computed dewatering rates are greatest within this region. By $12 \mathrm{~km}$ from the deformation front, rates of sediment movement in the prism decrease to about $10 \%$ of the incoming rate of movement.

2. A comparison with the Nankai Trough suggests that the overall rate of shortening may be greater in the Barbados Ridge complex, although the decrease in porosity with depth is less.

3. Arcward of $5 \mathrm{~km}$ from the deformation front, the greatest rate of fluid expulsion per unit volume of sediment occurs in the underthrust sediments. The total rate of water production by compaction of the underthrust sequence outside the model region may be as much as the total production within the region. The importance of these sediments as fluid sources suggests that future drilling should attempt to obtain more information about the physical properties of underthrust sequences.

\section{ACKNOWLEDGMENTS}

Financial support for this study was provided by a National Science Foundation Grant, OCE-8609745 We are grateful for numerous comments, suggestions, and insights by J. Casey Moore, Mark Reid, David Rogers, Hedeff Essaid, and the manuscript reviewers.

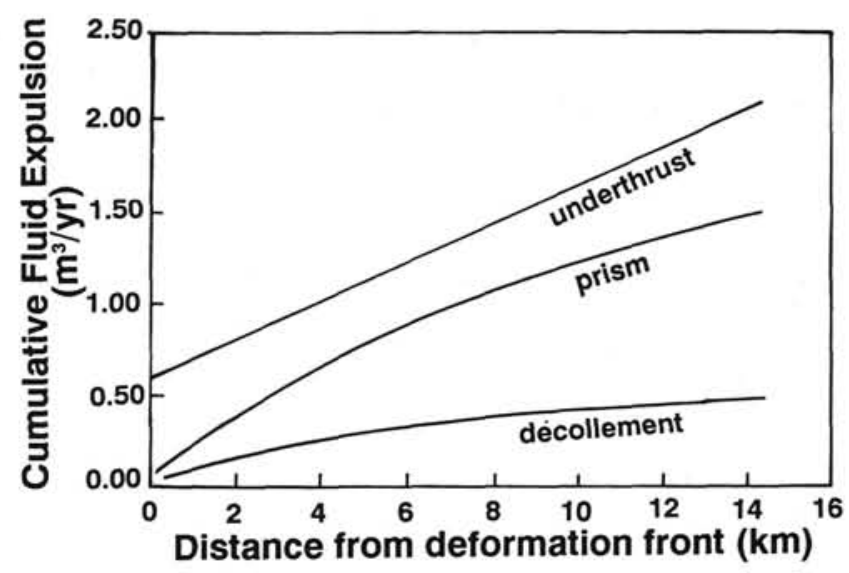

Figure 11. Total cumulative fluid expulsion from the prism, décollement, and underthrust domains as a function of distance from the deformation front. Note that the prism and décollement sediments lose porosity most rapidly near the deformation front, while the underthrust sediments maintain a relatively uniform rate of fluid generation.

\section{REFERENCES}

Bear, J., 1972. Dynamics of Fluids in Porous Media. New York (Elsevier Scientific Publishing Co.).

Biju-Duval, B., Moore, J. C., et al., 1984. Init. Repts. DSDP, 78A: Washington (U.S. Govt. Printing Office).

Bray, C. J., and Karig, D. E., 1985. Porosity of sediments in accretionary prisms, and some implications for dewatering processes. J. Geophys. Res., 90: 768-778.

Davis, D., Suppe, J., and Dahlen, F. A., 1983. The mechanics of foldand-thrust belts and accretionary wedges. J. Geophys. Res., 88: 1153-1172.

Dorel, J., 1981. Seismicity and seismic gap in the Lesser Antilles arc and earthquake hazard in Guadalupe. Geophys. J. R. Astron. Soc., 67: 679-695.

Etheridge, M. A., Wall, W. J., and Vernon, R. H., 1983. The role of the fluid phase during regional metamorphism and deformation. J. Meta. Geol.,1:205-226.

Hubbert, M. K., and Rubey, W. W., 1959. Role of fluid pressure in mechanics of overthrust faulting. Geol. Soc. Am. Bull., 70:115-166.

Karig, D. E., 1986. The framework of deformation in the Nankai Trough. In Kagami, H., Karig, D. E., Coulbourn, W. T., et al., Init. Repts. DSDP, 87: Washington (U.S. Govt. Printing Office), 927940.

Kulm, L. D., Suess, E., Moore, J. C., Carson, B., Lewis, B. T., Ritger, S. D., Kadko, D. C., Thornberg, T. M., Embley, R. W., Rugh, W. D., Massoth, G. J., Langseth, M. G., Cochran, G. R., and Scamman, R. L., 1986. Oregon subduction zone: venting, fauna, and carbonates. Science, 231:561-566.

Langseth, M. G., and Hobart, M. A., 1984. A marine geothermal study over deformed sediments of the subduction complex off Oregon and Washington. Eos, 65:1089.

MacDonald, K., and Holcombe, T., 1978. Inversion of magnetic anomalies and seafloor spreading in the Cayman Trough. Earth Planet. Sci. Lett., 40: 407-414.

Marlow, M. S., Lee, H. J., Wright, A. W., 1984. Physical properties of sediment from the Lesser Antilles Margin along the Barbados Ridge: Results from Deep Sea Drilling Leg 78A. In Biju-Duval, B., Moore, J. C., et al., Init. Repts. DSDP, 78A: Washington (U.S. Govt. Printing Office), 549-558.

Mascle, A., Moore, J. C., et al., 1988. Proc. ODP, Init. Repts., 110: College Station, TX (Ocean Drilling Program).

Minster, J. B., and Jordan, T. H., 1978. Present-day plate motions. J. Geophys. Res., 83:5331-5354.

Moore, J. C., and Biju-Duval, B., 1984. Tectonic synthesis. In BijuDuval, B., Moore, J. C., et al., Init. Repts. DSDP, 78A: Washington (U.S. Govt. Printing Office), 601-621.

Moore, J. C., Mascle, A., Taylor, E., et al., 1987. Expulsion of fluids from depth along a subduction-zone décollement horizon. Nature, 326:785-788. 
Moore, J. C., Mascle, A., Taylor, E., et al., 1988. Tectonics and hydrogeology of the northern Barbados Ridge: Results from Ocean Drilling Program Leg 110. Geol. Soc. Am. Bull., 100:1578-1598.

Seely, D. R., 1984. The significance of landward vergence and oblique structural trends on trench inner slopes. In Talwani, M., and Pitrnann, S. C., Eds., Island Arcs, Deep Sea Trenches, and Back-Arc Basins: Washington (Am. Geophys. Union Maurice Ewing Series, 1), 187198.

Stein, S., DeMets, C., Gordon, R. G., Brodholt, J., Argus, D., Engeln, J. F., Lundgred, P., Stein, C., Weins, D. A., Woods, D. F. A., 1988. A test of alternative Caribbean Plate relative motion models. J. Geophys. Res., 93: 3041-3050.

Sykes, R., McCann, W. R., and Kafka, A. L., 1982. Motion of Caribbean plate during last 7 million years and implications for earlier $\mathrm{Ce}$ nozoic movements. J. Geophys. Res., 87:10656-10676.
Tovish, A., and Schubert. G., 1978. Island arc curvature, velocity of convergence and angle of subduction. Geophys. Res. Lett., 5:329332.

Von Heune, R., and Lee, H., 1983. The possible significance of pore fluid pressures in subduction zones. In Watkins, J. S., and Drake, C. L., Eds., Studies of Continental Margin Geology: AAPG Mem., 34: 781-791.

Wright, A., 1984. Sediment accumulation rates of the Lesser Antilles intraoceanic arc, Deep Sea Drilling Project Leg 78A. In Biju-Duval, B., Moore, J. C., et al., Init. Repts. DSDP, 78A: Washington (U.S. Govt. Printing Office), 357-368.

Date of initial receipt: 14 March 1988

Date of acceptance: 22 March 1989

Ms 110B-164 